\title{
Austrian Higher Education Meets the Knowledge Society
}

\section{HANS PECHAR \\ University of Klagenfurt}

\section{ABSTRACT}

Austria has gone through two cycles of university reforms since the 1960s. The first aimed to open the universities to social and labour market demand and to make their structures more democratic and flexible. The second reform cycle dealt with glitches in the overly close relationship between universities and state bureaucracy. Bureaucrats still tightly controlled universities through line-budget funding and other forms of micro-management. This close dependency was abolished and university autonomy greatly strengthened when traditionally weak university leadership was replaced by a strong president and centralized administration, and by the creation of governing boards. The author argues that the second reform cycle was much influenced by Anglo Saxon models of university governance and constituted an almost total break with the traditional structures of Austrian universities. 


\section{RÉSUMÉ}

L'Autriche a entrepris deux grandes séquences de réformes universitaires depuis les années 1960. La première faisait accepter aux universités les demandes sociale et économique du marché du travail. La deuxième réforme cherchait à distancer l'université de l'État enseignant, arrangement caractérisé par une ingérence bureaucratique centralisatrice de longue date et minée par des mécanismes d'approbation détaillée des budgets universitaires. Cette relation de dépendance étroite a été abolie et l'autonomie a été établie grâce au renforcement du leadership universitaire par la nomination de recteurs présidents forts de leurs propres fiefs administratifs, et par l'établissement de conseils d'administration. L'auteur montre à quel point cette dernière réforme s'inspirait principalement de modèles anglo-saxons en matière de gouvernance universitaire, et constituait une rupture quasi-totale avec les structures traditionnelles des universités autrichiennes.

\section{INTRODUCTION}

In the last four decades, Austria has experienced two cycles of higher education reform, sharply differentiated by policy, and separated by a decade of consolidation. The first cycle began in the 1960s and peaked in the mid-1970s, putting higher education under the umbrella of welfare state policies, emphasizing student participation, allowing junior faculty members to participate in decision-making, and broadening research. The policy catchwords were "opening" and "democratization."

The second cycle followed international policy trends of the 1990s. It produced reform legislation granting full legal status to universities as public enterprises. The relevant buzz words are "deregulation" and "efficiency." 


\section{OPENING AN ELITE SYSTEM}

Governments in the 1960 s and 1970 s had many good reasons to take action in higher education policy. Austrian universities were in a bad shape. They remained elite institutions only in size, serving about five percent of the potential student population. The glorious research period of the late 19 th and early 20 th century was long over. The political catastrophes of the 1930s and 1940s resulted in two waves of expulsion for political and racial reasons that deprived universities of many able researchers (Stadler, 1988). Only the most active Nazis were expelled in the immediate post-war years; émigrés were rarely welcomed back. Universities were known for intellectual narrowness rather than innovation.

Educational reform became a political priority in the $1960 \mathrm{~s}$. The government set the course for educational expansion and modified the traditional chair system (Ordinarienuniversität). The overarching goal of this first reform cycle was to "open up" rigid elite structures (Pechar, 1996). It was vital to remove visible and hidden barriers that excluded many talented students. The spectrum of recognized disciplines and methodological approaches broadened to include sociology and political science. Finally, the structures and procedures of university selfgovernance changed so junior faculty and students had a limited say in decision-making.

The first cycle was triggered by a remarkable policy shift. For the first time, education was regarded not just as a matter of culture, but as an investment yielding economic and other social benefits, an important factor in economic growth and competitiveness. Most political actors thought student participation in advanced education had not kept pace with labour market demand. Educational opportunities had therefore to be expanded and access improved. Where formerly policy makers took it for granted that low participation rates in the elite tracks of secondary schools and in universities proved lack of talent, it now became obvious that the pool of talent by far exceeded the number of students in institutions of 
higher learning. The main policy goal became to make use of that hidden resource (Ausschöpfung der Begabungsreserven).

Policy makers took various measures to encourage student participation. They widened access to Gymnasium and other kinds ${ }^{1}$ of elite secondary education. Entrance exams to Gymnasium were loosened during the 1960s and abolished in 1971. This was an important signal to parents previously deterred by selection procedures. Within a few years, graduates from the secondary elite track (Maturanten) increased from $8 \%$ of the age cohort (1960) to 17\% (1971) and eventually to $40 \%$ (2002). Financial barriers to students from low and middle income families fell. In 1963, a new student aid act gave legal entitlement for grants to needy students who fulfilled certain minimal criteria of academic achievement. In 1971, tuition fees which had steadily diminished because they were never adjusted to inflation were abolished altogether, redefining higher education as a public good.

Most key figures in Austrian universities had little appetite to take more students. They worried that expansion of student numbers would eventually undermine the privileges of elite institutions. But Austrian universities had no effective means of resisting demand. All graduates from the elite track of secondary education were entitled to enrol at any Austrian university. Reforms that widened access to Gymnasium had inevitable consequences on first enrolment at universities. There was no legal way to keep students out of the ivory tower.

Despite professorial opposition, student numbers increased tremendously (see Table 1) This extraordinary growth was caused by a combination of rising participation rates on the one hand, and the growing age cohorts of the baby boomers on the other hand. During the early 1970s, growth was publicly welcomed as evidence of successful public policy. Graduates were no longer in short supply and there was some discourse on "overeducation." The first indications of graduate unemployment forced reassessment of the economic benefits of higher education, and a consequent shift in government policy. 


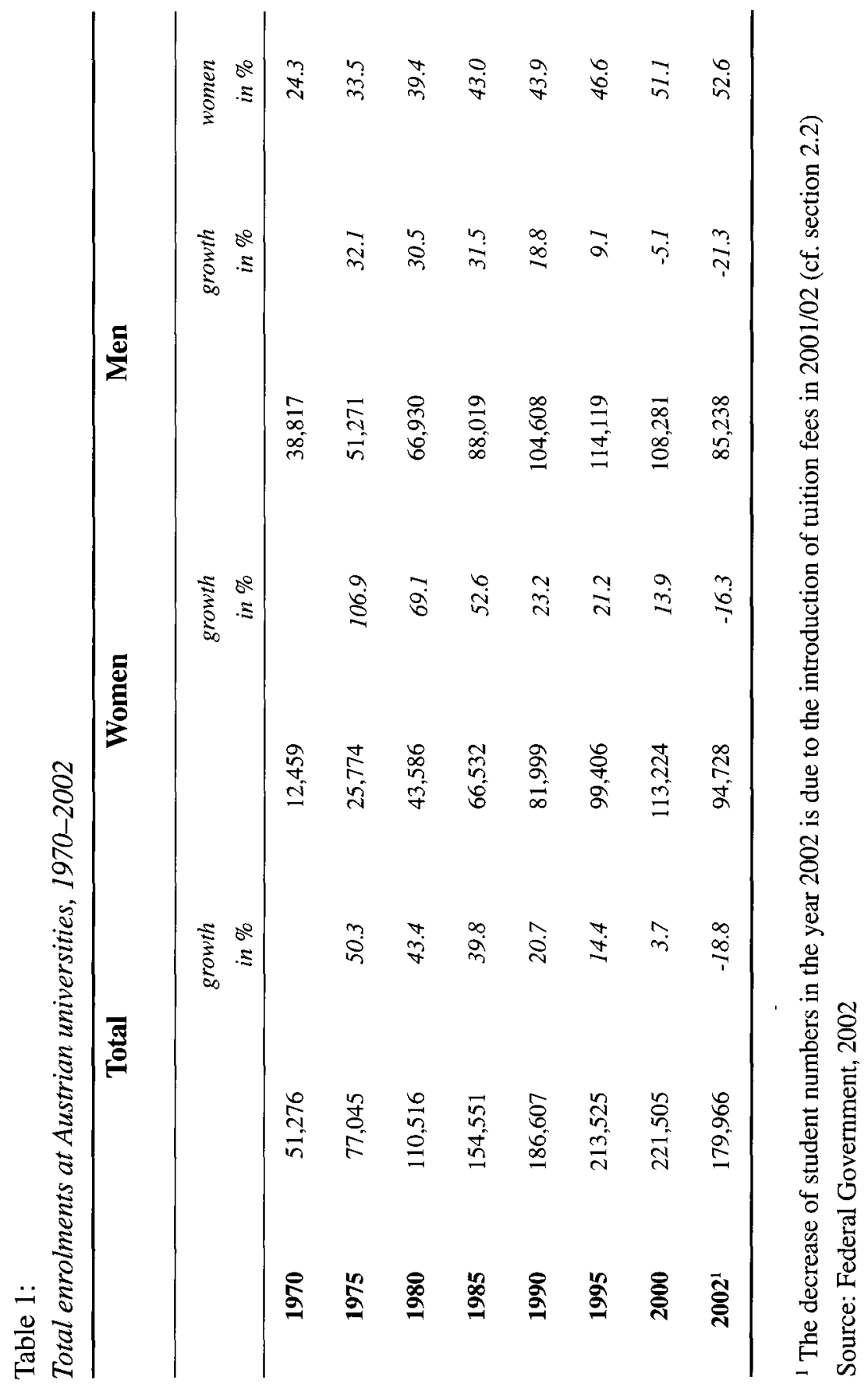

The Canadian Journal of Higher Education Volume XXXIV, No. 3, 2004 
Policy makers began to express concern over high drop-out rates and the long duration of programmes of study. ${ }^{2}$ It became increasingly evident that Austrian universities had not sufficiently adapted to large-scale higher education. Laissez-faire teaching and learning appropriate in a small and elite system, where students were treated as "apprentice researchers" free to determine their own course and pace of study, produced chaos in a system attempting mass higher education.

Most academics defended liberal style of teaching and learning as the only appropriate pattern of adult higher education - as opposed to school-like teaching (Verschulung). Students who did not fit in were by definition unsuited and unqualified for elite education and should look for alternatives. But there were few alternatives and Austria did not establish a non-university sector (Lassnigg \& Pechar, 1988).

Traditionally, the governance pattern of the elite system embraced a dualism between the administrative and academic sides. As a state agency, the university was, of course, subject to centralised decision-making by legislation and state bureaucracy; but all issues regarding teaching and research lay in the hands of the academic oligarchy - all chair-holders in charge of their own specialized field of research. The university saw itself as a self-governing community of scholars held together by common values. Problems were solved by chair-holding professors and the state bureaucracy. The rector was expected primus inter pares to represent the university, not to govern it, let alone manage it.

Academics saw no benefit in the university's achieving corporate autonomy. The educated elite saw it as a cultural obligation of the enlightened secular state (Kulturstaat) to enhance academic life. The state's duty was to protect the integrity and autonomy of universities and secure academic freedom from outside pressures, supporting academics as civil servants with life tenure. The implicit precondition of dual governance was mutual trust and respect between academics and policy makers and commonly shared assumptions about the nature of universities.

The first reform cycle seriously disturbed this tacit understanding. The government introduced modern policy concepts borrowed from other OECD countries. When a majority of the academic oligarchy opposed 
higher education reforms, the government enforced its policies through legislation and other means of regulation. Mutual trust and respect between academics and policy makers began to erode. The state was no longer a benevolent patron; academics no longer accepted and trusted the decisions of policy makers.

One area of conflict was quality assurance in teaching. It had been taken for granted that curriculum quality was the responsibility of academia: a loose legal framework for all aspects of teaching and learning allowed professors a high level of personal discretion. The first major reform act established a new legal basis for study courses, a major step towards formalization and harmonization of curricula under federal law and ministerial decrees. The commentary to the new act explained that education at universities was simply too important as to be left to academics (Götz, 1993). Using the new legal framework, policy makers intended to establish a reliable $e x$-ante control, assuring high quality while introducing social relevance to the curriculum. Most academics regarded such study regulation as inappropriate government interference.

The most heated area of conflict concerned the role and status of junior academics, formerly subordinate to chairholders as heads of academic units. Universities could only cope with rising student numbers by expanding junior faculty numbers and widening their responsibilities. Non-professorial academic staff took on an increasing range of academic functions. The University Organisation Act of 1975 (UOG 1975) granted students and junior academics limited voting power in collegial bodies. All attempts aimed to introduce participatory decision-making structures within the university naturally met stiff opposition from the academic oligarchy.

\section{A MANAGERIAL REVOLUTION?}

The 1980s were a time of consolidation after a period of severe changes and disappointment of high expectations triggered by reform. In general, Austrian developments ran in parallel with other OECD countries. Expectations based on naïve interpretations of human capital 
theory were suddenly confronted with graduate unemployment. When it became clear the promises of human capital and its benefits were not likely to be fulfilled, higher education ceased to be a top priority of public policy makers. As elsewhere, fiscal consolidation became the main concern of governments.

Thus, the alliance between reform-oriented academics and policy makers gradually ended. Much that formerly worked through implicit agreements was now based on formal rules and legal acts. Academics started to complain about excessive regulation and bureaucratic overload. That universities were state agencies was suddenly seen as a burden. The dominant view was that because universities were bound by a rigid state bureaucracy, they could not develop creatively. The gloomy academic mood of the time is portrayed in Rüegg (1987). A survey of expert opinions among 17 European states came to the conclusion that Austrian experts in higher education had lost nearly all confidence in their system (McDaniel, 1992). Academics now sought to liberate universities from state regulation. "Autonomy" became the catchword.

A second reform cycle was triggered, when politicians and senior civil servants began to agree with these views of state regulation. Increasingly, policy makers felt overwhelmed by the complexity of the mass higher education system. They lacked the necessary means (sufficient information and influence to motivate actors at lower levels) to implement "best solutions." Visions of "one best system" under central steering faded away. At the end of the 1980s, government abandoned its approach of stringent state regulation of all kinds of education institutions. This move towards deregulation was facilitated by fiscal consolidation. Senior civil servants had no interest in the ugly details of executing cuts and became quite sympathetic to arguments for enhanced autonomy of higher education institutions.

An important aspect of the second reform cycle was a change in the national role models to which policy makers referred. Policy borrowing (Halpin \& Troyna, 1995) plays a crucial role for the design and legitimation of fundamental reforms in small countries. During the first cycle, policy makers referred mainly to corresponding reforms and concepts in 
Germany, due to the common cultural tradition of both countries and the similarity of their systems. During the second reform cycle, there was growing interest into the Anglo-Saxon traditions of higher education, both the UK (Pechar, 2002) and later the US (Pechar, 1993). Concepts and policies totally alien to the Austrian tradition, such as accreditation or governing boards, were borrowed from the Anglo-Saxon context-a very deep change in the underlying paradigms of higher education policy. Governments abandoned the Kulturstaat tradition for the Anglo-Saxon policies of New Public Management. These new concepts gave rise to another wave of reforms. Within a few years, the architecture of Austrian higher education changed fundamentally.

The core reform of the second cycle was a fundamental re-organization of university governance, through the University Organisation Act of 1993-UOG 1993-and the University Act of 2002-UG 2002, which transformed institutions from state agencies into public enterprises.

In 1991, the education ministry published a draft for organizational reform promising to liberate universities from most forms of governmental control (Federal Government, 1991). Policy makers claimed this was a response to academic requests for more autonomy (Pechar \& Pellert, 1998). First, though, the government wanted to strengthen senior managerial positions at universities, replacing the rector-who represented the tradition of "first among equals" - with a president. New links were to be forged between universities and external stakeholders by introducing the Anglo-Saxon concept of trusteeship and by establishing governing bodies which would represent relevant (and powerful) stakeholders.

Policy makers believed universities would at least partly support this new policy of deregulation. But university autonomy can be interpreted in totally different ways by different actors. Academics still saw the notion of autonomy within the conceptual framework of the Kulturstaat tradition, while the government had already adopted the language of New Public Management. In the Humboldtian tradition, autonomy is used chiefly as a synonym for academic freedom of the individual, i.e., the full professor. Many professors saw autonomy as a buzz word for restoration of the "old regime" of academic oligarchy, of the Ordinarienuniversität. Junior 
faculty and students mainly favoured the concept of the autonomous "group university" and its collegial bodies in which-after the democratic reforms of the 1970 s - they had some representation. Those collegial bodies should govern the university without any interference from the state, whose sufficient and unconditional funding was simply taken for granted. Politicians and state bureaucrats advocated autonomy because they wanted to turn universities into enterprises which would be responsible not only for academic, but also for financial and administrative affairs. This interpretation of autonomy would go hand-in-hand with the development of a professional management and a strengthening of external scrutiny by supervisory boards (Höllinger, 1992).

A majority of academics strongly opposed the very idea of institutional autonomy, seen as an excuse for government abandonment of financial responsibility. The government softened its initial approach: senior leadership positions were strengthened, but their power was balanced by the significant influence of the collegial bodies. The influence of external stakeholders was reduced, and governing boards were replaced by advisory bodies. The ministry refused to give lump sum budgets to universities, arguing universities lacked sufficient managerial structures.

The University Organisation Act of 1993 (UOG 1993), a compromise between proponents and opponents of the reform, amounted to a cautious step towards autonomy. It was easy to see this was an intermediary stage. Probably the most important consequence of the UOG 1993 was the appearance of newly powerful rectors and deans. This small but influential group of senior academics were sensitive to external needs and pressures and could no longer be regarded as a group representing only the internal interests of academe, but increasingly as a mediating power.

It was the new rectors who complained that the UOG 1993 was only a half-measure. The government's first draft for the UOG 1993 had offered full legal-civil status to universities, and lump sum budgets to free universities from the state accountancy (Kameralistik), and it was this first version that the new academic managers favoured. Thus, the government gained a powerful ally in the university, some of whom were active in drafting the next reform law (Titscher et al., 2000). The majority 
of academics, however, continued to oppose the idea of full legal and civil status.

In the late 1990s, tensions between governments and academics intensified under continual fiscal cuts and renewed managerialism. In 2000 , a conservative government firmly changed the style of policy making. In the face of growing hostility, earlier social-democratic governments had retained the consensual politics of post-war years. The new conservative government proudly announced a "speed kills" approach forcing big changes within a few years. In 2001, a new organizational act was drafted and in 2002, after a few minor compromises, the University Act 2002 (UG 2002) was passed by Parliament (Sebök, 2002). Implementation began in 2004.

Universities ceased to be state agencies and became full legal entities, but were not privatized. They remain "legal persons under public law" (Körperschaften öffentlichen Rechts). The federal government retains responsibility for basic funding, but universities are exempt from the fiscal regulations of the federal budget (Kameralisitk) and instead receive a lump sum budgets at their own discretion.

Resources are allocated on the basis of performance contracts. Twenty per cent of the budget allocation will be based on indicators. The internal organization of universities - other than the general regulations regarding the decision-making structure-is not prescribed by law. Instead, organizational details are determined by statutes (Satzung) decided by the academic senate. Each university has a governing board (Universitätsrat) of between five and nine members, half elected by the academic senate, and the other half appointed by the Minister. Rectors are elected by the boards and thus more independent of all collegial academic bodies, but more dependent on the boards. The new universities become the employers of all academic and non-academic staff. Academics are no longer civil servants, but employed by private contracts.

This new organizational law is probably the most far-reaching reform since 1849, when Austria embraced the Humboldtian model. Austrian universities will acquire a kind of corporate autonomy unparalleled in the last 400 years. The new act makes Austria a leader in the "managerial 
revolution" on the European continent. Most policy makers regard this as a success. Most academics have mixed feelings about the imposition of the corporate decision-making structures onto universities.

The second reform cycle has a new policy on student expansion. Where the 1980s were shaped by a sceptical, sometimes even disapproving attitude to expansion, policy makers of the 1990s again agreed the social and economic value of popular educational aspiration. Subtle "coolingout" strategies gave way to a more positive and optimistic view of student expansion. The homogeneous character of Austrian higher education was now seen as an obstacle to further expansion. Private universities were legalized in 1999. The most important step in diversifying the system was establishment of the Fachhochschul sector in 1993. The government softened its severe ex-ante control and adopted a more liberal approach to quality assurance. Higher education became a "mixed good" which yields social and private benefits and hence should be funded by public and private contributions. In 2001, the government introduced tuition fees for the first time in 30 years.

The Fachhochschul sector was legally established in 1993 and started to enrol students the following year. Its main mission is to provide vocationally-oriented courses which can be effectively completed in three or four years (most Fachhochschul courses require a minimum length of study of four years). Since this new sector is built from completely new institutions, its growth is necessarily much slower than the university sector. In 2002/03, the sector had about 17,000 students and had already produced 10,000 graduates.

Compared to other OECD countries, the establishment of a nonuniversity sector in the 1990s was rather late. This at least partly explains the peculiar role Fachhochschulen play within Austrian higher education. If Austria had established Fachhochschulen in the late 1960s or early 1970 s, this sector would have been funded and organized on similar lines to the universities, as state agencies with line-by-line budgets. But in the early 1990s the policy context had changed. Fachhochschulen were designed as an alternative to universities not only in their educational profile, but also in their management, administration, and funding. 
The Fachhochschul policy was a more radical departure from Austrian traditions than UOG 1993 (Pratt \& Hackl, 1999). There were no legal ownership restrictions. All institutions were owned by "quasi-private" associations or corporations and governed by a professional management. Academic and non-academic staff were employed and appointed directly by the institution. Students were admitted in accordance with available study places. Curriculum decisions were made by academics in cooperation with institutional management. The final responsibility for quality was in the hands of an external professional body, the Fachhochschulrat, which guaranteed minimal standards of quality. Fachhochschulen were expected to vary widely in terms of profile and quality of their education. Fachhochschulen received a lump sum from the federal government based on student numbers and subsidiary funds from multiple public sources, including provinces, municipalities, and in some cases chambers.

The establishment of the Fachhochschul sector is regarded as the most significant success story of the last decade in Austrian higher education. This sector has already built a high reputation amongst students, employers, and the general public, and has established a different culture of learning to that of the universities. Students are expected to take the normal workload, and the institution must accept a high degree of responsibility for student needs. Early indications are that few students drop out (10-20\%) and that most complete their courses in "standard time."

During the 1970s and 1980s, courses and curricula in universities were controlled by Parliament, and any modifications usually required legislation. Political authorities claimed to define the "one best solution" for each level of education, but of course views on appropriate curricular measures differed according to contradicting expert opinions and political convictions. Policy makers and academics became increasingly dissatisfied with the slow pace of curricular reform.

The second reform cycle liberalized the paternalistic tradition of quality control. Public opinion leaders, the general public, and policy makers no longer believed in the "one best solution." It seemed to make better sense to allow a certain amount of competition between different curricular profiles. To protect students against unacceptably low quality offerings, Austria adopted Anglo-Saxon practices of accreditation. 
This liberal approach to quality control was first applied in the Fachhochschul sector, which empowered the Fachhochschulrat to accredit courses on a model strongly influenced by the example of the British polytechnics and the United Kingdom's Council for National Academic Awards (Pechar, 2002). A similar approach was regarded as imperative in 1999, when the new act established private universities. The main aim of the Austrian Accreditation Council (AAC) is to open the university sector to private suppliers. The Council scrutinizes minimum standards of applicants, such as number of permanent staff, research activities, admission procedures, range and variety of study courses, and financial liability.

For public universities, the present situation is quite different. In 1997, the tight ministerial ex-ante control of university studies was replaced by a new study law which granted significant autonomy to the universities and their study commissions, which establish and maintain study courses. Thus far this devolution of responsibility for curricula has not been balanced by external scrutiny, accreditation, approval, or suprainstitutional evaluation. The Ministry has promised establishment of an "evaluation agency" for 2004.

During the 1970s and 1980s, the idea of free higher education as a public good was rarely contested. When fiscal consolidation became the top priority, the growth rate of higher education expenditure fell, and the resultant decline in per-capita expenditure stirred debate on possible additional revenues from private sources.

Conservatives have never been enthusiastic about free higher education. The situation was quite different for the social democrats, who profoundly changed Austrian higher education during the early 1970s. Free higher education was regarded as the core of those reforms. But even in the social democratic camp, the fiscal crisis changed attitudes. During the 1990s, doubts arose whether this policy had met the big expectations of equality of educational opportunities. Had the social make-up of the Austrian student body really changed since the 1960s? A survey (Guger, 1994) concluded that about $30 \%$ of students come from families of the highest $10 \%$ income brackets. Students from disadvantaged were 
still strongly under-represented. It is doubtful that expansion has brought any significant change.

From the perspective of social justice, free higher education is much more ambiguous than most supporters acknowledge. It is mainly the better-off who benefit from the public expenditure required to provide free higher education. On the other hand, it remains true that fees can hamper access by low-income students. In order to prevent this, fees must be brought into line with the social condition of students and their ability to pay.

In 2000 , the newly elected conservative government decided to introduce tuition fees of 363 Euros per semester, beginning in the 2001/02 academic year. The move was controversial, especially since only two weeks previously the minister of education had promised in a TV interview that no fees would be introduced during the present legislative term. Critics pointed out that the fees provided no additional income to universities, since they were collected by the treasury as essentially a "student tax" to facilitate fiscal consolidation. Also, the government introduced "flat fees" for all enrolled students, with no differentiation between full-time and part-time students. ${ }^{3}$ Students who combine study with work, and hence require a longer duration of studies, would pay more for their degree than full-time students.

The most important question remained whether fees would function as a social barrier for students from low income families. It is too early to answer this question, based on empirical evidence. The fees are relatively low, and there is an exemption for students who are eligible for student aid. Evidence from the first three years suggest that fees caused no decline in the number of active students. Enrolment figures did declined by more than $20 \%$ (Table 1), but this can be explained as the exit of non-active paper students who under previous laissez faire conditions stayed enrolled for various reasons (section 1.1). Estimates based on examination statistics show that the number of active students ${ }^{4}$ remained stable (Pechar \& Wroblewski, 2002; Federal Government, 2002, p. 150). In 2001/02, when fees were first charged, there was about an $8 \%$ decline in the number of first enrolments, but this was compensated for during the immediately following years with higher than expected first enrolments. 


\section{CONCLUSION}

Although most Austrian academics emphasize the differences between the first and the second reform cycle, especially the contrast in their underlying policy paradigms, the two phases have much in common. Future historians of Austrian higher education might instead point out the common characteristics of reform policies since the $1960 \mathrm{~s}$, a period in sharp contrast to the former elite system.

The common ground of the two reform cycles is the diminishing role of government as benevolent patron of universities (Kulturstaat) on the Humboldtian model. The precondition of this pattern was a small, homogeneous system of universities held together by the common values of an educated elite - including senior civil servants, who ensured circumstances favourable to elite institutions. The emergence of a knowledge-based economy changed the social foundations of universities fundamentally and irrevocably. This tremendously boosted the prestige of research and teaching at universities, at the same time abolishing many privileges taken for granted during the elite period. Higher education became a need rather than a luxury, an absolute necessity in terms of social demand and economic competitiveness.

During the 1960s and early 1970s, it was easy to confuse the new economically driven reform policy with the old state benevolence. Governments increased funding and granted unprecedented attention and importance to universities. But a crucial difference soon emerged: governments no longer gave unconditional support to elite institutions as a matter of noblesse oblige. Public funding would henceforth be based on the expectation of social and economic returns. In this perspective the two reform cycles were two policies with a common goal-to make universities more responsive to social and economic demands. 


\section{Notes}

'Such as BHS, the professional schools at the upper secondary level.

${ }^{2}$ Austria belongs to the countries with the highest drop out rates (more than $50 \%$ ) and the longest duration of studies (7.5 years to the first degree) within the OECD (cf. OECD 2003).

${ }^{3}$ Although Austria has no formal part-time status for students, at least half of all students combine study with work.

4"Active students" were those who took at least one examination during a period of two years.

\section{References}

Federal Government. (1991). Die neue Universitätsstruktur (The new university structure). Reformkonzept (Green Paper). Wien: BMWF.

Federal Government. (2002). Hochschulbericht (Higher Education Report) 2002. Wien: BM:BWK.

Götz, E. (1993). Chronologie der Studienreform (Chronology of the reform of higher education) 1962-1966. In BMWF (Hrsg.), Materialien zur Studienreform I., Wien: BMWF.

Guger, A. (1994). Verteilungswirkungen der gebührenfreien Hochschulbildung in Österreich (Distributive effects of higher education without tuition). Forschungsbericht an das BMWF. Wien.

Halpin, D., \& Troyna, B. (1995). The politics of education policy borrowing. Comparative Education, 31(3), 303-310.

Höllinger, S. (1992). Universität ohne Heiligenschein. Aus dem 19. ins 21. Jahrhundert (University without halo - From the 19th to the 21st century). Wien: Passagen.

Lassnigg, L., \& Pechar, H. (1988). Alternatives to universities in higher education. Country Study: Austria. Paris: OECD.

McDaniel, O.C. (1992). The direction of higher education. Short report of a DELPHI study, Zoetermeer.

OECD. (2003). Education at a glance. Paris: OECD.

Pechar, H. (Hrsg.). (1993). Das amerikanische Hochschulsystem. Beiträge zu seinen Vorzügen, Problemen und Entwicklungstendenzen (American higher education - Its advantages, problems and trends). Zeitschrift für Hochschuldidaktik, Jg. 17, Heft 2-3. 
Pechar, H. (1996). Die “offene Gruppenuniversität" und ihre Grenzen (The open group university and its limitations). In T. Brandstaller (Hrsg.), Österreich 2 1/2, Anstöße zur Strukturreform. Wien: Deutike.

Pechar, H. (2002). Accreditation in higher education in Britain and Austria: Two cultures, two time-frames. In Tertiary Education and Management, Vol 8: 231-242.

Pechar, H., \& Pellert, A. (1998). Managing change: Organisational reform in Austrian universities. Higher Education Policy 11, 141-151.

Pechar, H., \& Wroblewski, A. (2002). Retrospektive Schätzung studienaktiver Studierender an Universitäten der Wissenschaften für den Zeitraum (Retroactive estimate of active university students) 1996/97-2000/01. Gutachten im Auftrag des BM:BWK. Wien 2002.

Pratt, J., \& Hackl, E. (1999). Breaking the mould in Austrian higher education. In Higher Education Review 32(1), 34-54.

Rüegg, W. (1987). Zementierung oder Innovation. Effizienz von Hochschulsystemen (Petrification or innovation - On the efficiency of higher education systems). Wien: Österreichische Rektorenkonferenz.

Sebök, M. (2002). Universitätsgesetz 2002 (University Act of 2002). Gesetzestext und Kommentar. Wien: WUV Universitätsverlag.

Stadler, F. (Hrsg.) (1988). Vertriebene Vernunft II. Emigration und Exil österreichischer Wissenschaft (Reason expelled: Emigration and exile of Austrian science). Wien: Jugend \& Volk.

Titscher, S., Winckler, G., Biedermann, H., Gatterbauer, H., Laske, S., Moser, R., Strehl, F., Wojda, F., \& Wulz, H. (Eds.). (2000). Universitäten im Wettbewerb: Zur Neustrukturierung österreichischer Universitäten (Universities in competition: On the restructuring of Austrian universities). München/Mering: Rainer Hampp Verlag. 